\title{
Reproductive Synchrony of the Hermatypic Corals, Acropora hemperchii and Pocillopora verrucosa, along the Egyptian Red Sea Offshore and Onshore Reefs: Environmental Constraints
}

\author{
Montaser A. M. Al-Hammady ${ }^{1}$, Awaad A. M. Elsyed ${ }^{2}$, Fattma M. A. Fouda ${ }^{3}$, Hussein N. M. Hussein ${ }^{4}$ \\ ${ }^{1,4}$ National Institute of Oceanography and Fisheries, Hurghada, Red Sea, Egypt \\ ${ }^{2}$ Department of Zoology, Faculty of Science, Al-Azhar University, Cairo, Egypt \\ ${ }^{3}$ Department of Zoology, Faculty of Girls, Ain- Shams University, Cairo, Egypt
}

\begin{abstract}
Histological investigations for the reproductive conditions of Acropora hemperchii and Pocillopora verrucosa in the onshore reefs at site 1, which impacted by oil pollution, and site 2 which, impacted by phosphate shipping, and those in the offshore ones at sites 3 and 4 at, respectively; each was impacted by diving activities, were studied. Both of the given species was found to be hermaphrodite broadcast spawners annually. The gonads of $P$. verrucosa were found on stalks arising from the column wall; but in A. hemperchii, the gonads fill the entire mesenteries. Moreover, there are pronounced differences in the timing and length of gametogenesis and spawning of $A$. hemperchii and $P$. verrucosa between different geographic regions. A. hemperchii showed the least productivity at the effected with oil pollution at site 1, represented by: $55 \%$ of mature oocytes and an additional $38 \%$ of immature oocytes. P. verrucosa declined to 46 \%of mature oocytes and 50\% of immature oocytes. The highest productivity of A. hemperchii was represented by $90 \%$ matures, $3 \%$ immatures and 7\% empty and for Pocillopora verrucosa increased to $92 \%$ matures, $2 \%$ immature, and $5 \%$ empty at the offshore site 2 , the site impacted by eutrophication as a result of phosphate shipment. The spawning season of A. hemperchii in the northern Red Sea at site 1, is two months later than in the southern site 2, where A. hemperchii starts spawning in May and extended to July. However, $P$. verrucosa begins one month early than A. hemperchii at the same site, and extends for three months also from April to June. Moreover, spawning of $P$. verrucosa at site 2 is one month early than at its spawning at site 1 . While, P. verrucosa at sites $3 \& 4$ starts spawning at April and extended for two months only.
\end{abstract}

Keywords: Red Sea, coral reef reproduction, synchronous, onshore and offshore reefs, breeding season, spawning

\section{Introduction}

Studying of coral reproductive cycles is an important part of our understanding base on the ecological processes of coral reefs and, by itself, is essential for their management and conservation. Successful coral reproduction is necessary for getting new colonies to a reef and the recovery of destroyed sites by natural or anthropogenic turbulence (Al-Hammady 2011).An understanding of coral reproductive cycles and the impact of environmental factors on reproduction is for that reason vital in comprehending the potential of this important part of the life cycle. That's why it important to conduct some regular monitoring and surveys for coral reefs reproduction, recruitment, ecosystem etc... to understand their behavior and what the main threats are.

Scleractinian corals reef sexual reproduction is important for monitoring and maintaining coral populations (Lirman et al. 2010; Al-Hammady 2011 and Larson et al. 2014). However, knowledge of scleractinian coral reproduction has progressively grown in the last 15 years, as reproductive data of $40 \%$ of known species from the tropical Pacific and 30\% of Caribbean coral species were available (Richmond and Hunter 1990 and Styan \& Rosser 2012). Reproduction of Red Sea coral species is still gap, where $6 \%$ were only investigated (Shlesinger and Loya1998).
The ongoing global renaissance in coral reproduction research is providing a wealth of new information on this topic, and has almost doubled the global database on coral reproductive patterns during the past two decades (Harrison 2011). Reproductive mode may be externally controlled by coral's morphological traits such as colony size, polyp size, oocyte diameter and gonad location (Rinkevich and Loya 1979a; Szmant 1986 and Van Veghel \& Kahmann 1994), by environmental factors such as different zoogeographic regions(Szmant 1986; Van Woesik 1995\& Tanner 1996), phylogenetic constraints (Harrison 1985), and also temperature (Al-Hammady, 2011).

In the Red Sea, most coral species were found to be hermaphrodite broadcast spawners, and only a few were hermaphrodite brooders or gonochoric broadcast spawners (Shlesinger and Loya 1985; Shlesingeret al. 1998;Baird et al. 2009). This is in accordance with the overall Indo-Pacific pattern (except Eastern Pacific; Baird et al., 2009; Baird et al. 2011; Stoddartet al. 2012), although intraspecific variability of reproduction modes was found, for example, in the coral Pocillopora verrucosa, which is a broadcast spawner in the Red Sea (Shlesinger andLoya 1985; Harrison 2011; Sawall\& Al-Sofyani 2015), but a brooder in the central Pacific (Richmond and Hunter 1990).

Within the Red Sea, however, there production mode of a given species seems to be consistent from north to south, although sexuality of some species may change between years. 


\section{International Journal of Science and Research (IJSR) ISSN (Online): 2319-7064 \\ Index Copernicus Value (2013): 6.14 | Impact Factor (2014): 5.611}

This was found during a long-term study on the hermaphrodite brooder Stylophora pistillata,where some colonies were hermaphrodite in one year and male or even sterile in another year (Rinkevich and Loya1987). Inconsistencies in reproduction modes might be due to energy limitations and/or stress conditions in some years (Rinkevich and Loya 1987; Larson et al. 2014), since reproduction is major energy expenditure. A substantial amount of energy for reproduction is derived from photosynthesis (Rinkevich1989; Leuzingeret al. 2012).

The lack of knowledge of the reproductive biology of the Red Sea coral species imposes many difficulties on studies dealing with the recruitment and distribution of corals, as well as on the design of monitoring, management and recovery programs of reef environments in Egypt (AlHammady 2011).

The current contribution is the first of a series and deals with the reproductive biology of Acropora hemperchii and Pocillopora verrucosa. This study offers results on the sexuality patterns, modes of reproduction, synchrony and spawning periods of these species, which occur sympatrically in the studied reefs.

\section{Material and Methods}

The reproductive condition of 288 colonies from of Acropora hemperchii and Pocillopora verrucosa were collected by SCUBA diving form two onshore and two offshore widely geographically separated areas, extending along the Egyptian Red Sea coasts (Fig.1). Moreover these sites impacted with different anthropogenic activities. The onshore reefs comprised site \#1 lies at the General Petroleum Company at Ras-Gharib City- Gulf of Suez and polluted by oil pollution, and site \#2 locates at the Old AlQuseir Harbor at Al-Quseir City and impacted by eutrophication as a result of phosphate shipment. The other two offshore reefs sites(sites \# 3\& 4) locate at the Small Gifton Island and Abo-Ramad Island, respectively; each located off Hurghada and impacted by diving activities.

Tissue samples from of Acropora hemperchii and Pocillopora verrucosa were obtained on a semi-monthly basis from June, 2013 to March, 2014. Sampling involved breaking off a branch from each colony. Because of the relatively small size of Acropora hemperchii and Pocillopora verrucosa, it was not possible to sample sequentially the same colony, and therefore, ten different colonies were sampled on each sampling day at each study reef. To reduce as possible within-reef variation in coral reproduction synchrony, all of Acropora hemperchii and Pocillopora verrucosa colonies collected were at a depth of $5 \mathrm{~m}$; all coral specimens were of similar size (colony height 8 to $12 \mathrm{~cm}$ ). The sampling regime was designed to minimize possible effects of natural environmental gradients (i.e. depth or wave action), as well as possible effects of colony size on the onset of gametogenesis and gonad abundance (Szmant- Froelich, 1985).

All coral specimens were fixed in $10 \%$ formalin for $24 \mathrm{~h}$ within a few minutes of collection. To increase the rate of decalcification, each branch was split in half with a chisel and decalcified in a solution of equal parts of 50\% formic acid and $20 \%$ sodium citrate solution according to Pearse (1968) and Rinkevich \& Loya (1979a), which was changed after 6 h. After decalcification, all coral tissue samples were washed in running tap water for $6 \mathrm{~h}$ and preserved in Bouin's solution (Humason, 1972).

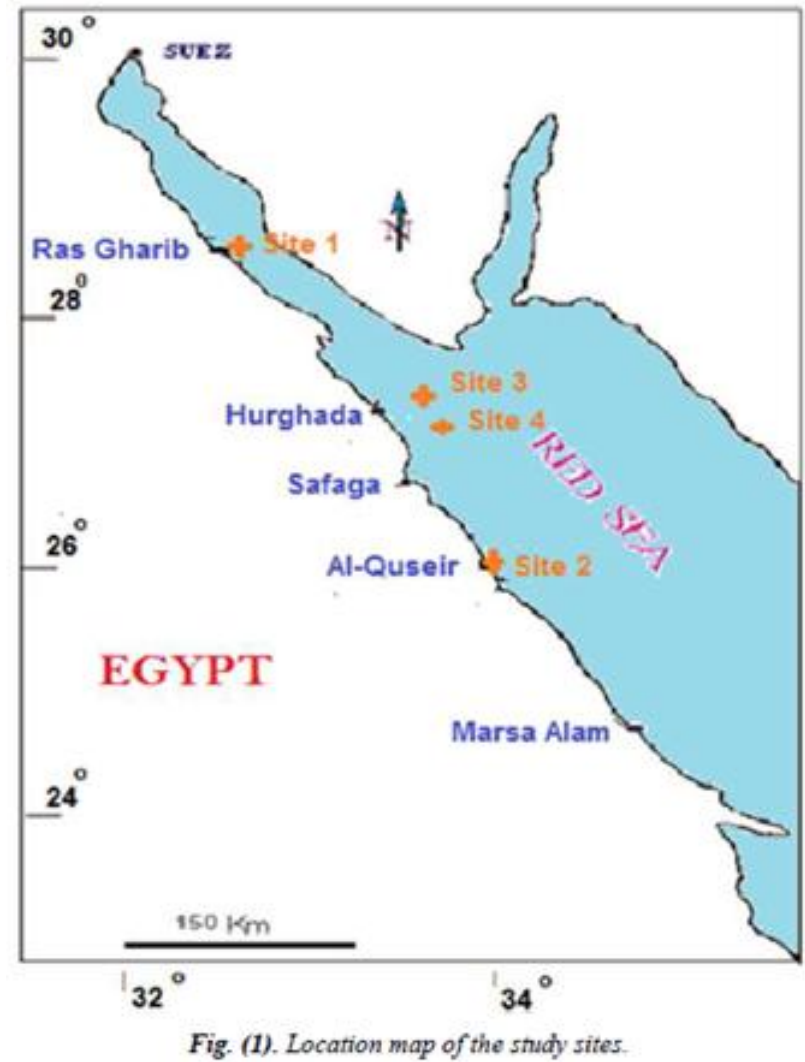

For histological analyses, tissue samples $\left(0.75\right.$ to $\left.1.50 \mathrm{~cm}^{2}\right)$ were taken from mid-branch according to Rinkevich \& Loya (1979b). All tissue samples were dehydrated in an ethanol series (Humason, 1972), cleared in toluene and embedded in Tissue Prep. A number of tissue samples from each reef had previously been sectioned to locate the region of the polypcontaining reproductive material. Thus, two slides with five to eight serial cross sections each were prepared from each tissue sample. All tissue sections were stained with Harris hematoxylin (progressive method; $40 \mathrm{~s}$ ) and counterstained with eosin (3 rain). For the quantitative analyses, two cross sections (one from each slide) were chosen randomly. Male and female gonads were investigated and all dimensions were measured with a calibrated ocular micrometer.

\section{Results}

The reproductive synchrony of Acropora hemprechii and Pocillopora verrucosa at offshore and onshore reefs in respect to the environmental impacts is quantify during the present study. Gonads were histologically examined every month, for approximately 10 months (from June 2013- March 2014). However, both of the given species were found to be hermaphrodite broadcast spawners annually. Gonad arrangement and morphology varied between these studied species. Gonads of Pocillopora verrucosa were found on stalks arising from the column wall. Ova and sperms are cooccurring within the same polyp, but were segregated between different pairs of mesenteries in body cavity. Acropora 


\section{International Journal of Science and Research (IJSR) ISSN (Online): 2319-7064 \\ Index Copernicus Value (2013): 6.14 | Impact Factor (2014): 5.611}

hemperchii, has gonads fill the entire mesenteries. Male and female gonads were segregated on different mesenteries in each polyp, and occupied one row in each mesentery (Fig 2). Variation between these species occurs in the degree of segregation of testes and ovaries, where three levels of segregation were observed. Broadcasting of Acropora hemperchii and P.verrucosa had annual gametogenic cycles lasting approximately 6 to 7 months. However, development of the oocytes and ripening of the eggs (oogenesis) starts first, followed by the onset of testis development for sperm production (spermatogenesis) from1-3months later.

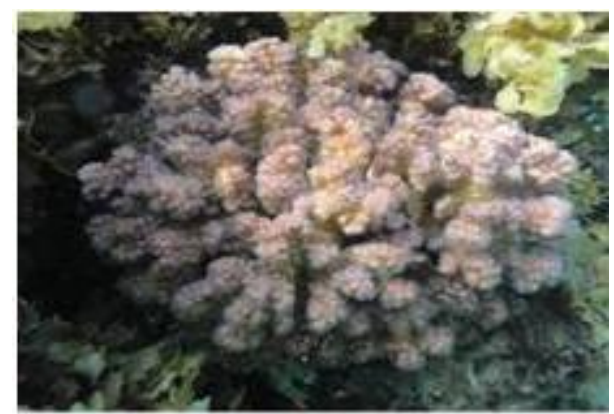

Pocillopora verrucosa

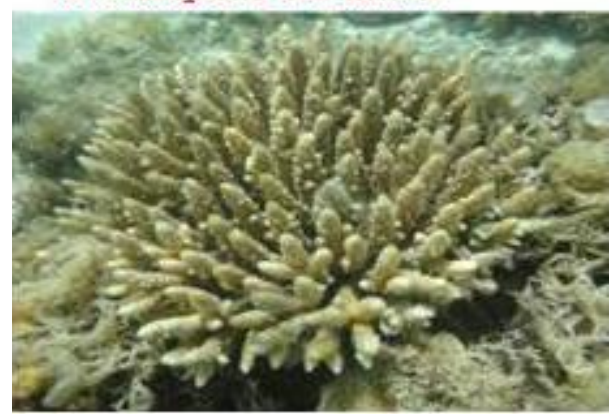

Acropora hemrechii

Fig. (2). The Studied species

At the present study, the results in Table (1) indicate that site \#1, the site impacted by oil pollution, showed the least productivity of the studied species, where 55 percent of Acropora hemperchii had mature oocytes and an additional 38 percent of immature oocytes, and $7 \%$ are empty. No oocytes were observed in the remaining colonies. In Pocillopora verrucosa, 46 percent had mature oocytes, 50 percent had immature oocytes and only $4 \%$ are empty. On the other hand, the highest productivity of Acropora hemperchii and Pocillopora verrucosawas observed at site \#2; the site impacted by eutrophication as a result of phosphate shipment. It was represented by $90 \%$ of mature, only $3 \%$ immature oocytes and $7 \%$ empty, for Acropora hemperchii and $92 \%$ of mature, only $2 \%$ immature oocytes and $5 \%$ empty for Pocillopora verrucosa. The productivity was also relatively high at sites \# 3 and 4 for the two species (Tab. 1).

Table 1: Percentage (\%) of Acropora hemperchii and Pocillopora verrucosa colonies with mature, immature, and no visible oocytes, during broadcast spawning season (from March to June) at the studied sites (Number of sampled colonies $=12$ from each sites).

\begin{tabular}{|c|c|c|c|c|c|c|c|c|}
\hline Species & \multicolumn{3}{|c|}{ Acropora hemperchii } & \multicolumn{4}{c|}{ P.verrucosa } \\
\hline \multirow{2}{*}{ Sites } & \multicolumn{2}{|c|}{$\begin{array}{c}\text { Onshore } \\
\text { reefs }\end{array}$} & \multicolumn{2}{c|}{$\begin{array}{c}\text { Offshore } \\
\text { reefs }\end{array}$} & \multicolumn{2}{c|}{$\begin{array}{c}\text { Onshore } \\
\text { reefs }\end{array}$} & \multicolumn{2}{c|}{$\begin{array}{c}\text { Offshore } \\
\text { reefs }\end{array}$} \\
\cline { 2 - 9 } & $\begin{array}{c}\text { Site } \\
1\end{array}$ & $\begin{array}{c}\text { Site } \\
2\end{array}$ & $\begin{array}{c}\text { Site } \\
3\end{array}$ & $\begin{array}{c}\text { Site } \\
4\end{array}$ & $\begin{array}{c}\text { Site } \\
1\end{array}$ & $\begin{array}{c}\text { Site } \\
2\end{array}$ & $\begin{array}{c}\text { Site } \\
3\end{array}$ & $\begin{array}{c}\text { Site } \\
4\end{array}$ \\
\hline $\begin{array}{c}\text { Mature } \\
(\%)\end{array}$ & 55 & 90 & 86 & 88 & 46 & 92 & 91 & 89 \\
\hline $\begin{array}{c}\text { Immature } \\
(\%)\end{array}$ & 38 & 3 & 8 & 7 & 50 & 2 & 3 & 5 \\
\hline $\begin{array}{c}\text { Empty } \\
(\%)\end{array}$ & 7 & 7 & 6 & 5 & 4 & 5 & 6 & 6 \\
\hline
\end{tabular}

At the current study, there are pronounced differences in the timing and length of gametogenesis and spawning of Acropora hemperchii and Pocillopora verrucosa between different geographic regions (Tab. 2 and Figs 3-4). The month of spawning of Acropora hemperchii in the northern site (site \#1) is two months later than in the southern site (site \# 2), where Acropora hemperchii tarts its spawning in May and extended to July. However ,Pocillopora verrucosa spawning season begins one month early than Acropora hemperchii at the same site (site \#1), and extended for three months from April to June. On the other hand, the spawning season of Pocillopora verrucosa at site \#2 is one month early than at in site \#1. While, Pocillopora verrucosa at sites\# 3\&4 started spawning at April and extended for two months only. This one or two-month offset is not surprising due to the difference in local temperature regimes and differences in environmental impact observed along the coast of the studied sites.

Table 2: Timing of coral spawning either directly observed or derived from gamete presence/absence in histological sections.

\begin{tabular}{|c|c|c|c|c|c|c|c|c|c|c|c|}
\hline \multirow{2}{*}{ Sites } & \multirow{2}{*}{ Species } & \multicolumn{10}{|c|}{ Months } \\
\hline & & $\mathrm{M}$ & $\mathrm{A}$ & $\mathrm{M}$ & $\mathrm{J}$ & $\mathrm{J}$ & $\mathrm{A}$ & $\mathrm{S}$ & $\mathrm{O}$ & $\mathrm{N}$ & $\overline{\mathrm{D}}$ \\
\hline \multirow{2}{*}{ Site 1} & Acropora hemperchii & - & - & $\sqrt{ }$ & $\sqrt{ }$ & $\sqrt{ }$ & - & - & - & - & - \\
\hline & Pocillopora verrucosa & - & $\sqrt{ }$ & $\sqrt{ }$ & $\sqrt{ }$ & - & - & - & - & - & - \\
\hline \multirow{2}{*}{ Site 2} & Acropora hemperchii & $\sqrt{ }$ & $\sqrt{ }$ & - & - & - & - & - & - & - & - \\
\hline & Pocillopora verrucosa & $\sqrt{ }$ & $\sqrt{ }$ & - & - & - & - & - & - & - & - \\
\hline \multirow{2}{*}{ Site 3} & Acropora hemperchii & - & $\sqrt{ }$ & $\sqrt{ }$ & - & - & - & - & - & - & - \\
\hline & Pocillopora verrucosa & - & $\sqrt{ }$ & $\sqrt{ }$ & - & - & - & - & - & - & - \\
\hline \multirow{2}{*}{ Site 4} & Acropora hemperchii & - & $\sqrt{ }$ & $\sqrt{ }$ & - & - & - & - & - & - & - \\
\hline & Pocillopora verrucosa & - & $\sqrt{ }$ & $\sqrt{ }$ & - & - & - & - & - & - & - \\
\hline
\end{tabular}

Month: January (J) to December (D).

\section{Discussion}

Examination of the literatures reveals that the present study comprised Acropora hemperchii and Pocillopora verrucosa is the first investigation of the reproductive biology at the Egyptian Red Sea coast. The present study showed that, the given species were hermaphrodite broadcast annually spawners. Similar findings were reported by Harrison (1985)

\section{Volume 5 Issue 1, January 2016




\section{International Journal of Science and Research (IJSR) \\ ISSN (Online): 2319-7064 \\ Index Copernicus Value (2013): 6.14 | Impact Factor (2014): 5.611}

and Leuzinger et al. (2012). The majority of the coral species at Caribbean and Pacific regions were broadcast gametes (Shlesinger, et al, 1998). While, only two species, Alveopora daedalea and Seriatopora caliendrum brood and release their planulae. Stylophora pistillatais the only brooding species reported from the Red Sea (Rinkevich and Loya 1979a\&b;Sawallet al., 2014).Furthermore, recent researches demonstrated that mode of reproduction may vary in some species. For example, Pocillopora damicornis (Ward 1992;Banguera-Hinestrozaet al. 2012) and Goniastrea aspera (Sakai 1997) exhibit broadcast spawning as well as brooding. The different modes of reproduction, brooding versus broadcasting, did not follow taxonomic lines. Reproductive mode may be externally controlled by environmental factors (Stimson 1978; Van Woesik 2010; Baird et al. 2009) suggested that brooding or broadcasting patterns are determined by depth. Deep sea species are predominantly broadcasters, while species in shallow water brood planulae. Further research, however, has revealed that both brooding and broadcasting species inhabit shallow water (Kojis and Quinn 1982a; Shlesinger \& Loya 1985; Harrison and Wallace 1990). Reproductive differences among species may result from habitat conditions in different zoogeographic regions (Szmant 1986; Van Woesik 1995 and Tanner 1996).

The present investigation found that Acropora hemperchii and Pocillopora verrucosa had annual gametogenic cycles lasting approximately 6 to 7 months, while oogenesis starts first, followed by spermatogenesis, 1-3 months later. These results agree with Shlesingeret al. (1998). They also pointed to the onset of oogenesis preceded spermatogenesis by 2 to 4 months

The decrease of Acropora hemperchii and Pocillopora verrucosa productivity of mature oocytes in site \#1 is not surprisingly, where this site is impacted by oil pollution. Al-Hammady (2011) and Al-Hammady and Mahmoud (2013) recorded similar results, that northern Red Sea reef, impacted by oil pollution, showed lower fertility than reefs at the south. Moreover, oiling impaired gonad development in both brooding (Peters et al., 1981; Rinkevichand Loya, 1979a) and spawning corals (Guzmán and Holst, 1993). In inverse, the site impacted with phosphate (site \#2), recorded the highest productivity in mature oocytes of Acropora hemperchii and Pocillopora verrucosa. These results agree with the finding of Ammar et al.(2012) and Sawall et al. (2011). They showed an increase in testes and egg numbers in Acropora humilis and Stylophora pistillata, and also concluded that phosphorus enrichment seems to be considerably less destructive than oil pollution (Ward and Harrison2000). Jessen et al. (2013) demonstrated that corals exposed to elevated level of phosphorus produced more oocytes and spermarise than control colonies. The reproductive condition in the Acropora hemperchii and P.verrucosa assemblage at sites $3 \& 4$ is very similar to that estimated in Acropora assemblages on the Egyptian coast of the northern Red Sea, where $85 \%$ of colonies from 12 species had mature oocytes in Marsa Alam in April 2008 and $99 \%$ of colonies from 17 species have mature oocytes in Hurghada in April 2009 (Hanafy et al., 2010).
The preceding spawning of the studied species one or two months later in the northern site (site \#1) than in the southern site (site \# 2) is not surprising due to the difference in local temperature regimes. The present results confirm the finding of Bouwmeester et al.(2014). They reported that Acropora species the Gulf of Aqaba were spawning two months later compared with those in the northern and central Red Sea. It is well known from the previous findings that the breeding season of coral reefs differs in both different localities and different species (Bairedet al. 2002; Rosser and Gilmour 2008; Gilmour et al., 2009; Rosser and Baired 2009). Kojis and Quinn (1981\&1982) reported that, Acropora sp. spawned over a 7 months period extends between October and April. In contrast, Mangubhai (2009) and Shlesinger and Loya (1985) found that Acropora sp. released gametes from January to March. However, most of the species in the Red Sea reproduce during the summer months (Shlesinger and Loya 1985).

\section{Conclusion}

The present study documents the coral spawning in the field and reported that it happens in the period extending from March to June. Corals at the southern Red Sea begin spawning faster. The results of this study can be used as a baseline for the coral reproduction studies in the northern Red Sea region. These results showed also that, oil pollution at site \# 1 reduced significantly coral maturity; on contrast, phosphorus at site \#2 increased remarkably coral productivity.

\section{Recommendation}

The obtained results can be used in:

1) Helping to select the best time for any marine project or coral translocation.

2) Corals don't have any reproductive spermaries or oocytes during summer (June - August) due to hot weather and temperature during summer.

3) Coral reefs can use as bioindicators for pollution and eutrophication.

\section{References}

[1] Al-Hammady, M.A.M. (2011). Patterns of bleaching and fertility in thetwo Red Sea corals, Stylophora pistillata and Acropora humilis as biomonitors of environmental impacts. Fac. Sci. Assiut Univ., Ph. D. thesis, 482 Pp.

[2] Al-Hammady, M. A. M. and Mahmoud, M. A. (2013). The Effect of Expanding Coastal Urban, Industrial Centers, Ports and Tourism on the Red Sea Coral Reefs Egypt. Proc. The International Conference of Environmental Sciences (ICES), 21- 22.

[3] Ammar, M.S.A., Obuid-Allah, A.H.and Al-Hammady, M.A.M. (2012). Coral growth and skeletal densities in relation to environmental impacts. In: INOC-CNRS, International Conference on Land-Sea Interactions in the Coastal Zone Jounieh - LEBANON, 06-08.

[4] Atkinson, M. J., Carlson, B. and Crow, G. L. (1995). Coral growth in high nutrient, low-pH seawater: a case study of corals cultured in Waikiki Aquarium, Honolulu, Hawaii. Coral Reefs, 14: 215 - 223.

[5] Baird, A.H., Guest, J.R. and Willis, B.L. (2009). Systematic and bio geographical patterns in the 


\section{International Journal of Science and Research (IJSR) \\ ISSN (Online): 2319-7064 \\ Index Copernicus Value (2013): 6.14 | Impact Factor (2014): 5.611}

reproductive biology of Scleractinian corals. Annu. Rev. Ecol. Evol. Syst., 40:551-571.

[6] Baird, A.H., Marshall, P.A. and Wolstenholme, J.K. (2002).Latitudinal variation in the reproduction of Acroporain the Coral Sea. Proc. $9^{\text {th }}$ Int. Coral Reef Symp., 1: 385-389.

[7] Baird, A.H., Blakeway, D. R., Hurley, T.J. and Stoddart, J.A. (2011). Seasonality of coral reproduction in the Dampier Archipelago, northern Western Australia. Marine Biology, 158:275-285.

[8] Banguera-Hinestroza, .E, Sawall, Y., Al-Sofyani, A., Wham, D., Schnetzer, J., Roder, C., LaJeunesse, T. and Voolstra, C. (2012). The genetic diversity of the coral-dinoflagelate diversity in the Red Sea. Abstract. In: $12^{\text {th }}$ international coral reef symposium, Cairns, Australia.

[9] Bouwmeester, J., Baird, A.H. and Chen, C.J. (2014). Multi-species spawning synchrony within scleractinian coral assemblages in the Red Sea. Coral Reefs Journal of the International Society for Reef Studies ISSN 0722-4028 , DOI 10.1007/s00338-014-1214-6, 1-13.

[10]Fadlallah, Y. H. (1983). Sexual reproduction, development and larval biology in scleractinian corals. A review. Coral Reefs, 2: 129-150.

[11]Frisch, A. J.,Ulstrup, K. E. and Hobbs, J. A.( 2007). The effects of clove oil on coral: an experimental evaluation using Pocillopora damicornis (Linnaeus). $J$. Exp. Mar. Biol. Ecol., 345: (2), 101-109.

[12] Gilmour, J.P., Smith, L.D.and Brinkman, R.M. (2009). Biannual spawning, rapid larval development and evidence of self-seeding for scleractinian corals at an isolated system of reefs. Mar. Biol., 156:1297-1309.

[13] Grigg, R. W. (1995). Coral reefs in an urban embaymentin Hawaii: a complex case history controlled by natural and anthropogenic stress. Coral Reefs, 14: 253-266.

[14] Guzman, H. and Holst, I. (1993). Effect of chronic oilsediment pollution on the reproduction of the Caribbean reef coral Siderastrea siderea. Mar. Pollut. Bull., 26: 476-282.

[15]Hanafy, M.H., Aamer, M.A.and Habib, M.(2010). Synchronous reproduction of corals in the Red Sea. Coral Reefs. 2010; 29(1): 119-124.

[16]Harrison, P.L.(1985). Sexual characteristics of scleractinian corals: systematic and evolutionary implications. In: Proc. of the $5^{\text {th }}$ intern. coral reef congress, Tahiti, 1985, Vol. 4:337-342.

[17]Harrison, P.L. (2011). Sexual Reproduction of Scleractinian Corals.Springer Science +Business Media B.V. 2011

[18]Hawkins, J. P. and Roberts C. M. (1993). Effects of recreational SCUBA diving on coral reefs: trampling on reef-flat communities. J. Appl. Ecol., 30:25-30.

[19] Humason, G. L.(1972). Animal tissue techniques, 641 pp. San Francisco: W. H. Free man and Company.

[20] Jessen C, Villa L, Javier F, Bayer T, Roder C, Aranda M, Wild C and Voolstra CR (2013) In-situ effects of eutrophication and overfishing on physiology and bacterial diversity of the Red Sea Coral Acropora hemprichii. PLoS One 8:e62091 doi: 10.1371/journal.pone.0062091.

[21] Kojis, B. L. and Quinn, N. J. (1981). Aspect of sexual reproduction and larvae development in shallow water hermatypic coral Goniastrea australensis (Edwards and Haime 1857). Bull. Mar. Sci., 31: 558-573.

[22] Kojis, B. L. and Quinn, N. J. (1982). Reproduction ecology of two Faviid corals (Scleractinia). Mar. Ecol. Prog. Ser., 8:251-255.

[23]Kotb, M. A.,Al-Agwan,M.,Al-Shaikh,Z.,Al-Yami,K., Banajah, H., DeVantier, A.,Eisinger,L., Eltayeb,M. M., Hassan, M., Heiss, G., Howe, S., Kemp, J., Klaus, R., Krupp, F., Mohamed, N., Rouphael, T., Turner, J. and Zajonz, U. (2004). Status of coral reefs in the Red Sea and Gulf of Aden in 2004. In: Wilkinson, C. (ed.): Status of coral reefs of the world. Australian Institute of Marine Science, Townsville, p. 301.

[24]Larson, E.A., Gilliam, D.S., Padierna, M.L.and Walker, B.K. (2014). Possible recovery of Acropora palmate (Scleractinia:Acroporidae) within the Veracruz Reef System, Gulf of Mexico: a survey of 24 reefs to assess the benthic communities. Rev. Biol. Trop., Vol. 62, No. 3, p. 75-84.

[25] Leuzinger, S., Wills, B. and Anthony, K.N. (2012) Energy allocation in a reef 1576 coral under varying resource availability. Mar. Biol., 159:177-186.

[26]Lirman, D., Bowden-Kerby, A., Schopmeyer, S., Huntington, B.,Thyberg, T., Gough, M., Gough, T., Gough, R. and Gough, Y. (2010) A window to the past: documenting the status of one of the last remaining 'megapopulations' of the threatened staghorn coral Acropora cervicornis in the Dominican Republic. Aquatic Conservation: Marine and Freshwater Ecosystems, Vol. 20, No. 7, p. 773-781.

[27] Mangubhai, S. (2009). Reproductive ecology of the scleractinian corals Echinoporagemmaceaand Leptoria Phrygia(Faviidae) on equatorial reefs in Kenya. Invert. Reprod. Dev., 22: 213-228.

[28] Meyer, J. L. and Schultz, E. T. (1985). Tissue condition and growth rate of corals associated with schooling fish. Linmol. Oceanogr., 30: 157- 166.

[29] Pearse, A. G. E. (1968). Histochemistry: theoretical and applied, J. \& A. Churchill Ltd, London, V1- 759 p. Boston: Little, Brown and Company 1968.

[30] Peters, E. C., Meyers, P. A., Yevich, P. P. and Blake, N. J. (1981). Bioaccumulation and histopathological effects of oil on a stony coral. Mar. Pollut. Bull., 12: 333-339.

[31] Richmond, R.H.and Hunter, C.L. (1990). Reproduction and recruitment of corals: comparisons among the Caribbean, the Tropical Pacific, and the Red Sea. Mar. Ecol.Prog.Ser., 60:185-203.

[32] Rinkevich, B. and Loya, Y. (1979a). The reproduction of the Red Sea coral Stylophorapistillata. I. Gonads and planulae. Mar. Ecol. Prog. Ser., 1, 133-144.

[33] Rinkevich, B. and Loya, Y. (1979b). The reproduction of the Red Sea coral Stylophora pistillata. II. Synchronization in breeding and seasonality of planulae shedding. Mar. Ecol. Prog. Ser., 1, 145-152.

[34] Rinkevich, B.andLoya, Y. (1987).Variability in the pattern of reproduction of the coral Stylophora pistillata at Eilat, Red sea: a long-term study.Biol. Bull., 173:335-344.

[35] Rinkevich, B. and Loya, Y. (1989). Reproduction in regenerating colonies of the coral Stylophora pistillata. In: Luria M. (ed.) Environmental quality and ecosystem stability, 257-265.

[36] Rosser, N.L. and Baird, A.H. (2009). Multi-specific coral spawning in spring and autumn in far north-western 


\section{International Journal of Science and Research (IJSR) ISSN (Online): 2319-7064 \\ Index Copernicus Value (2013): 6.14 | Impact Factor (2014): 5.611}

Australia. In: Proceedings of the 11th international coral reef symposium, Ft. Lauderdale, 2008, Vol. 1, pp 366-370.

[37] Rosser, N.L. and Gilmour, J.P. (2008). New insights into patterns of coral spawning on western Australian reefs. Coral Reefs, 27:345-349.

[38] Sakai, K. (1997). Gametogenesis, spawning and planula brooding by the reef coral Goniastrea aspera (Scleractinia) in Okinawa, Japan. Mar. Ecol. Prog. Ser., 151:67-72.

[39] Sawall, Y. and Al-Sofyani, A. (2015). Biology of Red Sea Corals: Metabolism, Reproduction, Acclimatization, and Adaptation.Springer Earth System Sciences, DOI 10.1007/978-3-662-45201-1_28.

[40] Sawall Y, Al-Sofyani A, Banguera-Hinestroza E, Voolstra CR and Wahl M (2014) Spatio-temporal analyses of zooxanthellae physiology of the coral Pocillopora verrucosa along large-scale nutrient and temperature gradients in the Red Sea. PLoS ONE 10.1371/journal.pone.0103179.

[41] Sawall, Y., Teichberg, M.C., Seemann, J., Litaay, M., Jompa, J.,and Richter, C. (2011) Nutritional status and metabolism of the coral Stylophora subseriata along a eutrophication gradient in Spermonde Archipelago (Indonesia). Coral Reefs, 30:841-853.

[42] Sebens, K. P. (1994). Biodiversity of coral reefs: what are we losing and why? American zoologist, 34: 115133.

[43] Shlesinger, Y., and Loya, Y. (1985). Coral community reproductive patterns: Red Sea versus the Great Barrier Reef. Science, 228:1333-1335.

[44] Shlesinger, Y., Goulet, T., and Loya, Y.(1998). Reproductive patterns of scleractinian corals in the northern Red Sea. Mar. Biol., 132(4): 691-701.

[45] Stimson, J.S.(1978). Mode and timing of reproduction in some common hermatypic corals of Hawaii and Enewetak. Marine Biology., 48:173-184.
[46] Stoddart, C., Stoddart, J., and Blakeway, D. (2012). Summer spawning of Poritesluteafrom north-western Australia. Coral Reefs, 31:787-792.

[47] Styan, C.A. and Rosser. N.L.. (2012). Is monitoring for mass spawning events in coral assemblages in north Western Australia likely to detect spawning? Marine Pollution Bulletin, 11: 2523-2527.

[48] Szmant, A.M. (1986). Reproductive ecology of Caribbean reef corals. Coral Reefs, 5:43-54.

[49] Szmant-Froelich, A. (1985). The effects of colony size on the reproductive ability of the Caribbean coral Montastrea annularis (Ellis and Solander). Proc. 5th int. Syrup. Coral Reefs, Symp., Vol. 4, p. 295-300, Tahiti.

[50] Tanner, J.E. (1996). Seasonality and lunar periodicity in the reproduction of pocilloporid corals. Coral Reefs, 15:59-66.

[51] Van Veghel, M.L.J, and Kahmann, M.E.H. (1994). Reproductive characteristics of the polymorphic Caribbean reef building coral Montastrea annularis. II. Fecundity and colony structure. Mar. Ecol. Prog. Ser., 109: 221- 227.

[52] Van Woesik,R. (1995). Coral communities at high latitudes are not pseudo populations: evidence of spawning at $32^{\circ} \mathrm{N}$. Japan. Coral Reefs, 14:119-120.

[53] Van Woesik, R (2010). Calm before the spawn: global coral spawning patterns are explained by regional wind fields. Proceedings of the Royal Society B: Biological Sciences., 277:715-722.

[54] Walker, D. I. and Ormond, R. F. G. (1982). Coral death from sewage and phosphate pollution at Aqaba, Red Sea. Mar. Pollut. Bull., 13(1): 21-25.

[55] Ward, S. (1992). Evidence for broadcast spawning as well as brooding in the scleractinian coral Pocillopora damicornis. Marine Biology., 112:641-646.

[56] Ward, S. and Harrison, P. (2000). Changes in gametogenesis and fecundity of acroporid corals that were exposed to elevated nitrogen and phosphorus during the ENCORE experiment. J. Exp. Mar. Biol. Ecol., 246,179221

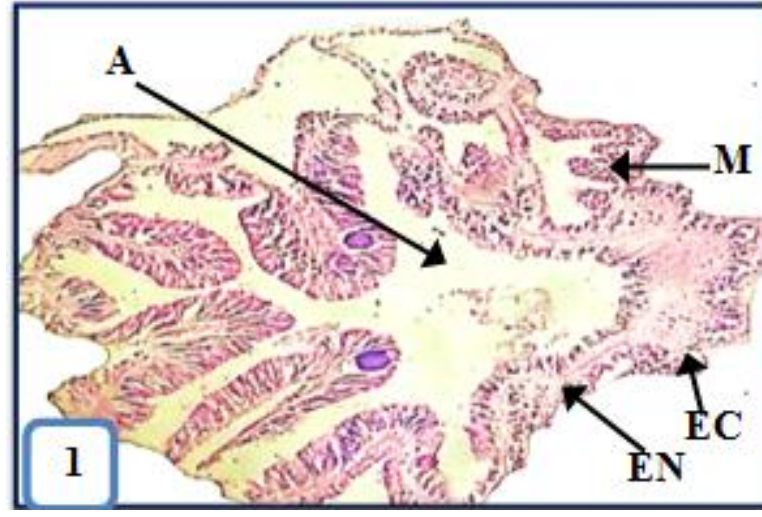




\section{International Journal of Science and Research (IJSR) \\ ISSN (Online): 2319-7064}

Index Copernicus Value (2013): 6.14 | Impact Factor (2014): 5.611
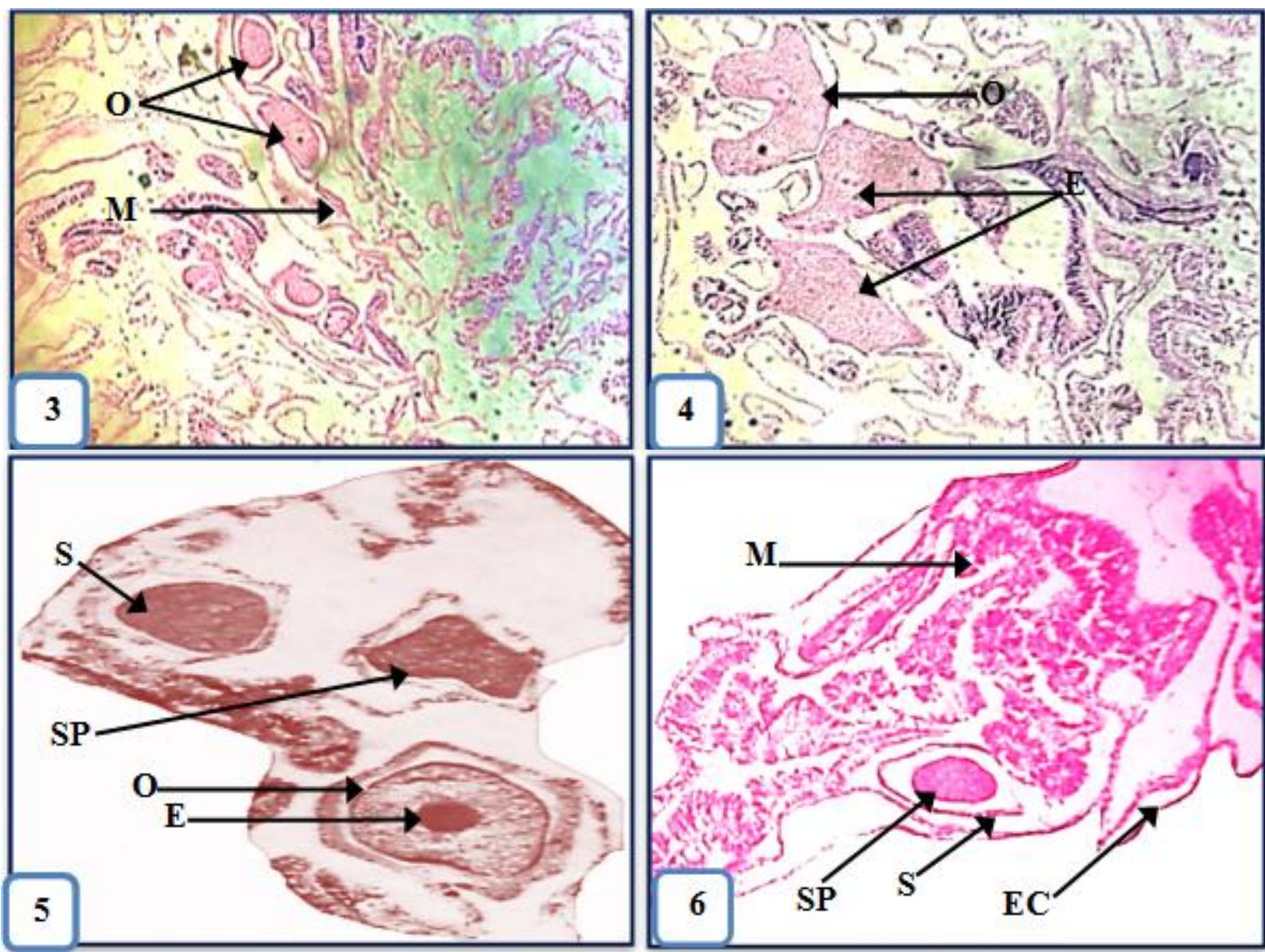

Figure 3: Histological investigations of Acroporahemperchii

1- A general structure of the polyp: Histological transverse section of polyp explains:mesentery (M), Actinopharynx (A), Ectoderm(EC) and Endoderm.

2- Extension of male gonads on mesenteries(M), male gonads of Acropora hemperchii (S) and sperms (Sp).

3- Transverse section in Acropora hemperchii at site \# 2, showing: mesentery(M) andfemale gonads (O).

4- Ovary containing mature eggs (E) at site \#3.

5- Female gonad (O) with mature eggs (E), and male gonad (S), with sperms (Sp)at site \# 4.

6- Transverse section of Acropora hemperchii at site \#1 mesentery (M), male gonads (S) and ectoderm (EC).
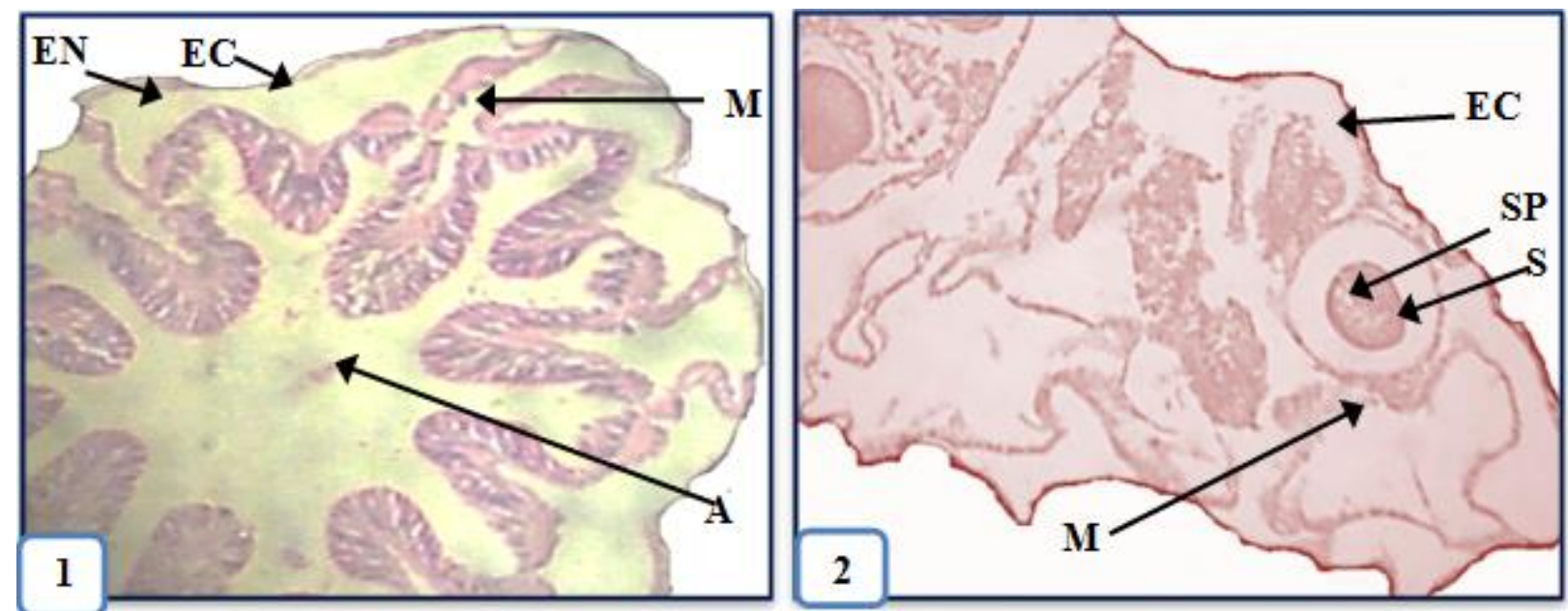
International Journal of Science and Research (IJSR)

ISSN (Online): 2319-7064

Index Copernicus Value (2013): 6.14 | Impact Factor (2014): 5.611
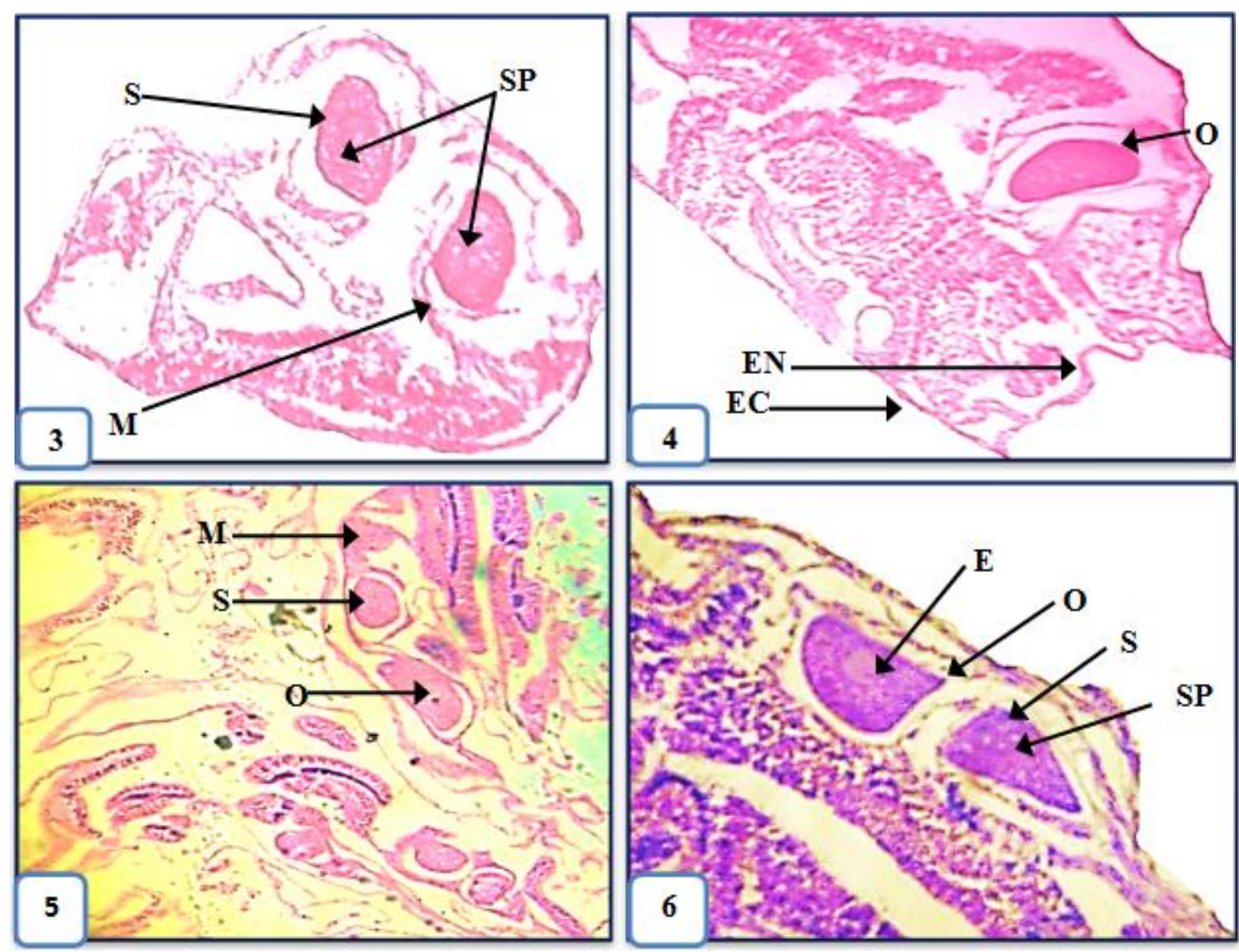

Figure 4: Histological investigations of Pocilloporaverucosa

1- A general histological structure (T.S.) of the polyp shows: mesentery (M),actinopharynx (A),ectoderm (EC)and endoderm (EN).

2- Extension of male gonads on mesenteries (M), male gonads of $P$. verucosa $(\mathrm{S})$ and sperms $(\mathrm{Sp})$.

3- Male gonads of $P$. verucosaat site \#1 with sperms (Sp) and mesenteries (M):.

4- Female mature gonads $(\mathrm{O})$ of $P$. verucosaat site \#4, ectoderm (EC) and endoderm (EN).

5- Transverse section of $P$. verucosa at site \#3, male gonads (S) and female gonads(O)on mesenteries (M).

6- Male gonads (S) with sperms(SP), female gonads (O) with mature eggs (E) at site \# 2. 